\title{
УДОСКОНАЛЕННЯ ТЕХНОЛОГІЇ РОБОТИ ОПЕРАТОРІВ ПАРКУ ВАНТАЖНИХ ВАГОНІВ РІЗНИХ ФОРМ ВЛАСНОСТІ
}

\author{
Канд. техн. наук В.В. Кулешов, магістри Р.Е. Даниленко, А.С. Лупир \\ СОВЕРШЕНСТВОВАНИЕ ТЕХНОЛОГИИ РАБОТЫ ОПЕРАТОРОВ ПАРКА ГРУЗОВЫХ \\ ВАГОНОВ РАЗНОЙ ФОРМЫ СОБСТВЕННОСТИ
}

\author{
Канд. техн. наук В.В. Кулешов, магистры Р.Э. Даниленко, А.С. Лупырь

\section{IMPROVED TECHNOLOGY WORK TRAIN OPERATORS FREIGHT WAGONS OF DIFFERENT OWNERSHIP FORMS}

\author{
Cand. of techn. sciences V. Kuleshov, masters R. Danilenko, A. Lupyr
}

Наведено аналіз кількості, структури інвентарного та власного парків вагонів в Украӥні. Виконано аналіз частки операторів перевезень на ринку перевезень залізниць України, власного парку вантажних вагонів в управлінні Державного підприємства «Український транспортно-логістичний центр» та вагонів в управлінні операторских компаній.

Складність транспортного ринку операторів перевезень можливо описати моделлю транспортного ринку операторів перевезень «Fitness Landscape». Зусилля, щчо приймаються операторами перевезень та структурними підрозділами залізниць, носять нелінійний характер. Перевага взаємозалежних систем полягає в тому, щзо виникає можливість одержання економічного ефекту завдяки економіиі зростаючої віддачі.

Ключові слова: залізниця, модель, оператор перевезень, парк вагонів, транспортний ринок.

Приведен анализ количества, структуры инвентарного и собственного парков вагонов в Украине. Выполнен анализ доли операторов перевозок на рынке перевозок железных дорог Украины, собственного парка грузовых вагонов в управлении Государственного предприятия «Украинский транспортно-логистичекий центр» и вагонов в управлении операторских компаний.

Сложность транспортного рынка операторов перевозок возможно описать моделью транспортного рынка операторов перевозок «Fitness Landscape». Усилия, которые прилагаются операторами перевозок и структурными подразделениями железных дорог, носят нелинейный характер. Преимущество взаимозависимых систем заключается в том, что возникает возможность получения економического эффекта благодаря экономике возрастающей отдачи.

Ключевые слова: железная дорога, модель, оператор перевозок, парк вагонов, транспортный рынок.

An analysis of the number, structure, inventory and own fleet of cars in Ukraine. The analysis of the share of transport operators in the transport market of railways of Ukraine, its own fleet of freight cars in the management of the State Enterprise "Ukrainian freight logisticheky center" and wagons in the management of operating companies.

The complexity of the transport market transport operators is possible to describe a model transport market transport operators «Fitness Landscape». The character of oscillations required car fleet transport operators on the total size and structure can be justified using stochastic methods. Random events that can be held or not held in the calculations, there is a traffic volume transport operators that have the optimal value of the park own cars to allow the volume of transported goods. Consequences of the efforts being made by operators of transportation and structural divisions of the railways, are not linear. The advantage of interdependent systems is that there is the possibility of obtaining economic effect due to the economy of increasing returns.

Keywords: car fleet, the transport market, model, railway, transport operators. 
Вступ. У цей час залізничний транспорт Європейського союзу (СС) має частку близько $16 \%$ ринку внутрішніх вантажних перевезень. На автомобільні перевезення припадає більше $70 \%$ усіх вантажних тонно-кілометрів [1]. Стратегія росту ЄС до 2020 року, Біла книга транспорту - політичні ініціативи, націлені на задоволення попиту в умовах підвищення мобільності парків, збереження та залучення нових обсягів перевезень, забезпечення безпеки елементів транспортної інфраструктури, необхідності переходу на «зелені» види транспорту (з автомобільного транспорту на залізничний).

Для залізничного сектора завдання вдосконалення організаційно-технологічної моделі керування парком вантажних вагонів різної форми власності 3 урахуванням пріоритетного обслуговування відправників вантажу, вантажоодержувачів $є$ актуальним.

Прогнозоване до 2050 року збільшення обсягів перевезень Європейської залізничної транспортної системи на $80 \%$ може бути досягнуте при вдосконаленні й розробленні нових організаційно-технологічних бізнесмоделей керування парком вантажних вагонів різної форми власності 3 урахуванням пріоритетного обслуговування користувачів залізничних послуг.

Постановка проблеми у загальному вигляді, її зв'язок з важливими науковими та практичними завданнями. Завдання першого й другого етапів виконання Державної цільової програми реформування залізничного транспорту України на 2010-2019 роки $[1,2]-$ розмежування функцій державного та господарського управління на залізничному транспорті передбачають формування вертикально інтегрованої системи господарського управління залізничним транспортом України.

Такі ж процеси вже відбулися в деяких залізничних адміністраціях (ЗА) держав СНД [3]. Одна 3 основних цілей перетворення подальший розвиток ринку ремонту вантажних вагонів за рахунок збільшення рівня конкуренції i якості надаваних послуг. Створення дочірніх товариств ВАТ «РЖД» у сфері ремонту вантажних вагонів дає змогу забезпечити довгострокові потреби залізничного транспорту в планових видах ремонту вантажних вагонів, підвищити економічну ефективність комплексу. Однак потребують свого вирішення питання взаємодії 3А 3 відправниками вантажу, вантажоодержувачами в частині використання рухомого складу різних перевізників.

Пріоритетним напрямком технічного реформування залізничного транспорту $\epsilon$ удосконалення технологій, систем взаємодії із користувачами залізничних послуг відправниками вантажу, операторами рухомого складу, експедиторами, і застосування нових інструментів керування доставкою вантажу. Причини вдосконалення організаційнотехнологічної моделі використання вантажних вагонів різної форми власності на залізницях обумовлені тим, що на інфраструктурному просторі відбувається взаємодія великої кількості учасників ринку: залізниць, операторів перевезень, власників рухомого складу, вагоноремонтних підприємств, інфраструктури, координація всіх учасників перевізного процесу на базі однакових вимог 3 організації руху.

Аналіз останніх досліджень i публікацій. У вказаному нормативному та організаційних документах $[1,2]$ при організації перевезень докладно не враховані питання удосконалення єдиної технології процесу перевезень операторських компаній - власників рухомого складу (ОК). У роботах $[3,4]$ запропоновані моделі взаємодії інфраструктури та ОК не враховують питання розроблення єдиного технологічного процесу $3 \mathrm{~A}$ та ОК. У роботах [5-8] хоча і були розглянуті сучасні підходи організаційно-технологічної моделі керування парком вантажних вагонів різної форми власності, але потребують розв'язання питання удосконалення технології роботи операторів рухомого складу парку вантажних вагонів різної форми власності на сортувальних станціях та вузлах залізниць України.

Визначення мети та задачі дослідження. Мета та задачі дослідження удосконалення технології роботи операторів рухомого складу парку вантажних вагонів різної форми власності на сортувальних станціях та вузлах залізниць України.

Основна частина дослідження. В Україні транспортний ринок операторів перевезень розвивається. Станом на 30.03.2015 року інвентарний парк вантажних вагонів України 36,2 тис. ваг або 20,2\% від загального парку 179,1 тис. ваг. Власний парк вантажних вагонів - 142,9 тис. ваг і становить $79,8 \%$ від 
загального парку. У тому числі парк власних вагонів від загального становить: піввагонів $93,7 \%$, критих - 93,0\%, інших - 67,2\%, цистерн - 65,6\%, рефрижераторних $-55,5 \%$, платформ - 15,6\%. Аналіз кількості і структури інвентарного та власного парків вагонів в Україні станом на 30.03.2015 року наведений на рис. 1.

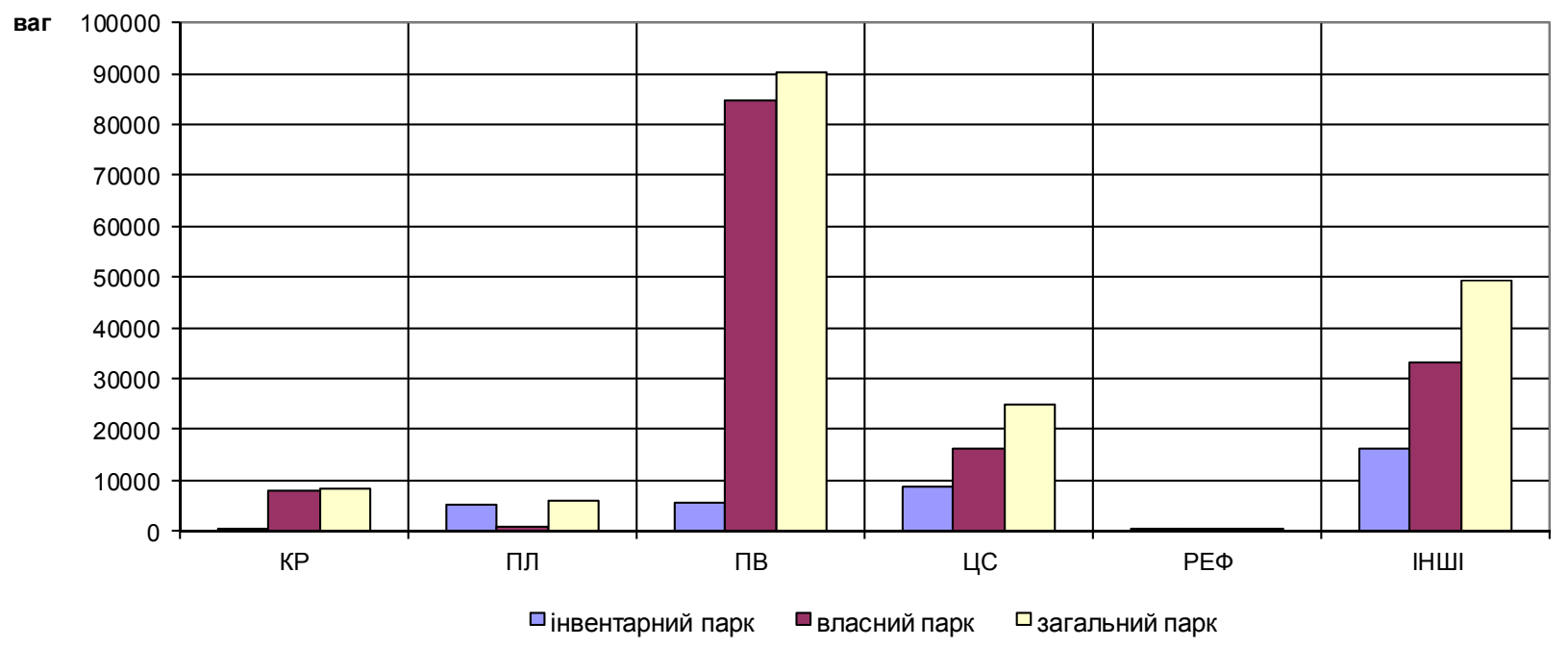

Рис. 1. Аналіз кількості і структури інвентарного та власного парків вагонів в Україні станом на 30.03.2015 p.

У вагонах, якими оперує структурний підрозділ Укрзалізниці - Державне підприємство «Український транспортнологістичний центр» (УТЛЦ), у 2013 році було перевезено 141 млн т вантажів, що на 0,16\% більше, ніж у 2012 році. За станом на 01.04.2014 p. УТЛЦ оперував 58,1 тис. ваг державних вагонних компаній Укрзалізниці, у т. ч.: ДП «Дарницький вагоноремонтний завод» (ДВРЗ) - 40,5 \%, ДП «Український державний центр по експлуатації спеціалізованих вагонів» «Укрспецвагон» (УСВ) - 36,9\%, ДП «Український державний центр залізничних рефрижераторних перевезень «Укррефтранс» (УРТ) - 15,6\%, ДП «Стрийський вагоноремонтний завод» (СВРЗ) - 6,4\%, ДП «Український державний центр транспортного сервісу Ліски» (Ліски) - 0,5\%. Для оптимізації перевізного процесу УТЛЦ здійснює експедирування перевезень вантажів у вагонах приватних власників у межах України.

Аналіз власного парку вантажних вагонів в управлінні УТЛЦ 3 розподілом за родом рухомого складу станом на $30.03 .2015 \mathrm{p}$. наведений на рис. 2.
Парк власних вагонів ОК 41,7 тис. ваг, у т. ч.: ТОВ «Лемтранс» - 49,3\%, ТОВ «Металургтранс» - 12,2 \%, ДП «ТрансгарантУкраїна» - 9,5\%, ПАТ «Укренерготранс» $8,7 \%$, ДП «Укрспецвагон» - 6,8\%, ТОВ «ЕвразТрансУкраїна» - 4,5\%, ТОВ «ЕКС ІМ ТРАНС» - 2,7\%, ТОВ «Металургійна транспортна компанія» - 2,3\%, ТОВ «Центротранс» - 1,3\%, ТОВ «Українська нова перевізна компанія» - 0,6\%, ТОВ «ТРАНС ЕНЕРДЖИ» - 0,6 \%, ТОВ «Укрметалургтранс» $-0,6 \%$, ТОВ «Інтерлізінвест» - 0,4\%, ТОВ «Днепркартранс» - 0,3 \%, ТОВ «ТКЛОГІСТИК» - 0,2 \%, ТОВ «ТЕК «Енерготранс» - $0,1 \%$. Аналіз стану парку вагонів в управлінні операторских компаній в Україні 3 розподілом за родом рухомого складу станом на 30.03.2015 р. наведений на рис. 3.

Організаційно-технологічну модель управління парком вантажних вагонів різної форми власності на залізницях України при взаємодії ЗА та ОК в умовах Єдиної системи управління парком вантажних вагонів (ЄСУ ПВВ) доцільно сформувати на основі моделі стохастичного програмування, що порівняно 3 існуючою дасть змогу визначити парк власних 
вагонів для забезпечення прогнозованого обсягу перевезень вантажів 3 урахуванням нормативного обороту власного вагона, статичного навантаження, коефіцієнта нерівномірності перевезень, а також коефіцієнта витрат на технічне обслуговування та перевезення $[5,6]$.

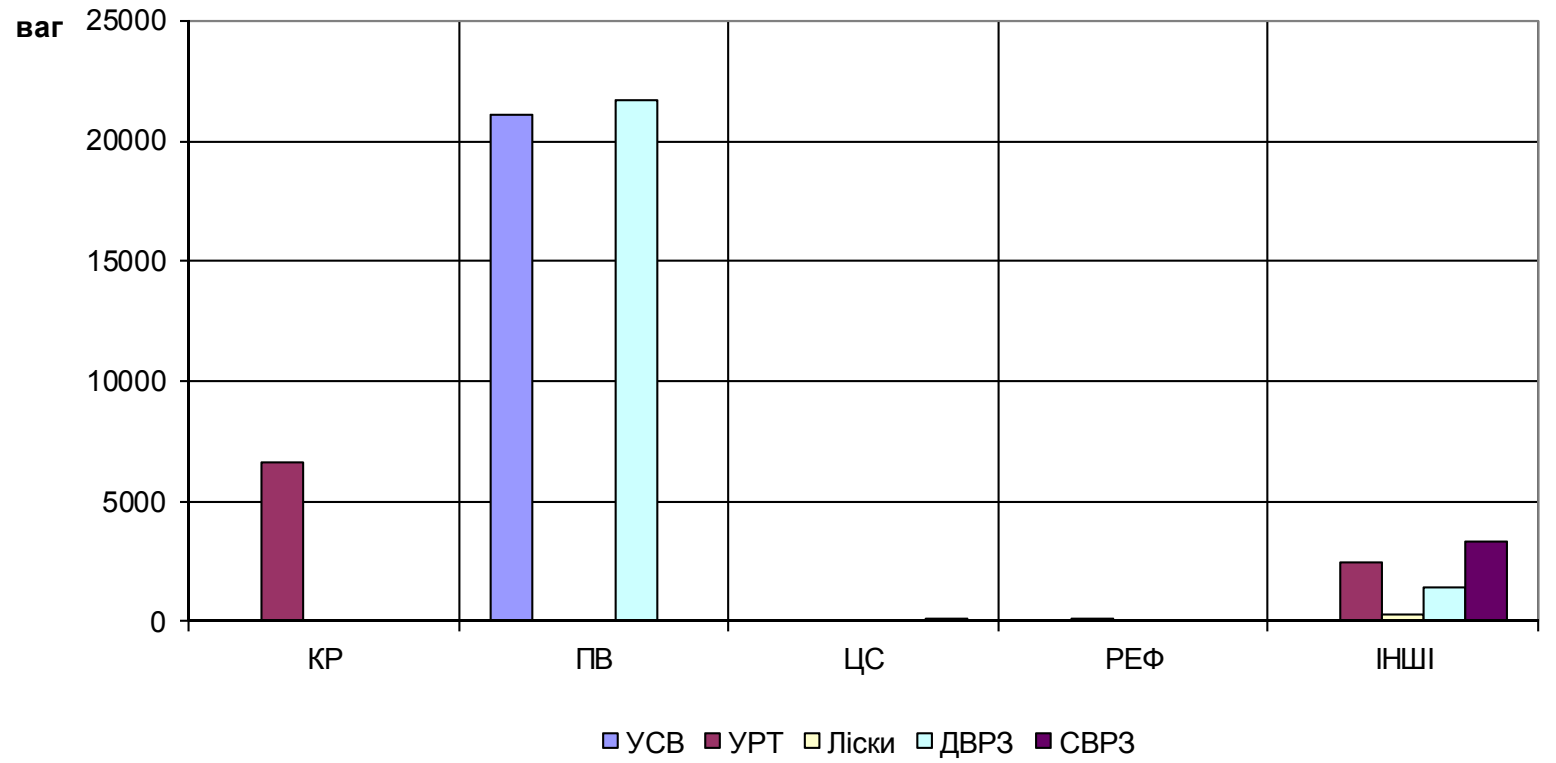

Рис. 2. Аналіз власного парку вантажних вагонів в управлінні УТЛЦ з розподілом за родом рухомого складу станом на 30.03.2015 p.

Характер коливань необхідного парку вагонів OK за загальною величиною i структурою може бути обгрунтований 3 використанням стохастичних методів [10]. Випадковою подією, що може відбутися або не відбутися при проведенні розрахунків, є обсяг перевезень ОК, які мають оптимальну величину парку власних вагонів для забезпечення можливого обсягу перевезень вантажів.

Вихідним моментом аналізу економікотехнологічних систем є відмова від моделі, у якій використовується гігантський механізм. У рамках традиційної моделі, якщо потрібні більш високі економічні показники, то необхідно побудувати могутнішу модель. Таким чином, логіка економічного росту приводить до нарощування обсягу системи. Якщо ресурси i технічні можливості допускають, то завдання економічного росту є вирішеним. Звідси основний акцент на ресурси i нові технології. Тонким місцем традиційної моделі $\epsilon$ те, що гігантська модель росту повинна працювати на транспортній мережі, що уже не можна стримати механічними прийомами.
Складність транспортного ринку операторів перевезень можливо описати моделлю транспортного ринку операторів перевезень «Fitness Landscape» (див. рис. 4), запропонована Стюартом Кауффманом [9]. Через те, що ландшафт навколо стрімко змінюється, то спроби збільшення обсягів вантажних перевезень можуть не привести до успіху не через невдачі, а тому, що в якийсь момент 3 незалежних причин може не бути вагонного парку.

3 іншого боку, мережа взаємозв'язків може підсилювати не тільки ризики, але i можливості росту. У мережевому середовищі не завжди діє фундаментальний закон класичної економічної теорії - закон зменшуваної віддачі. Продукція або технологія, потрапивши в мережу, може одержати підтримку не стільки завдяки своїм конкурентним перевагам, а завдяки тим зв'язкам, які створили їй можливості просування на транспортному ринку. У цьому випадку виникає ефект зростаючої віддачі, про який не могло бути i мови в умовах конкуренції. 

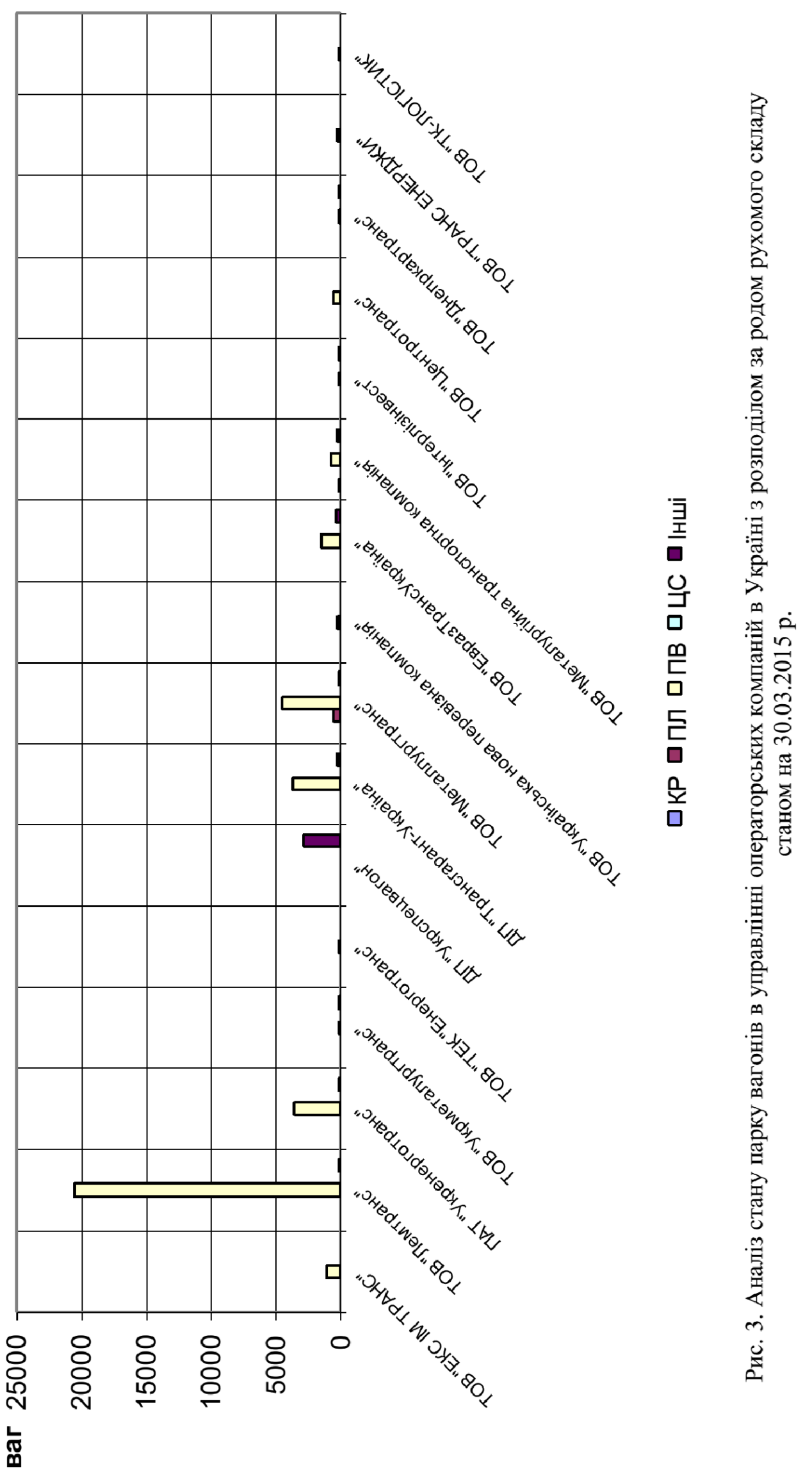


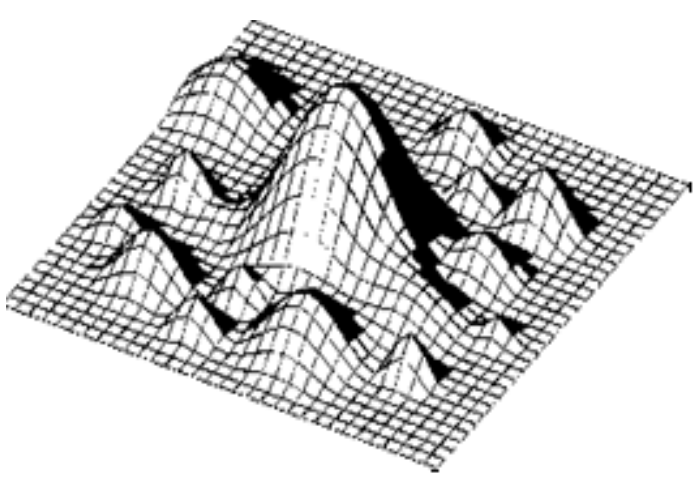

Рис. 4. Модель транспортного ринку операторів перевезень «Fitness Landscape»

Приєднання кожного нового учасника до існуючих мереж відбувається не випадково, тобто в рамках моделі random attachment (випадкового приєднання), а деяким своєрідним шляхом, описуваним за допомогою моделі preferential attachment (кращого приєднання). Суть останньої моделі полягає в тому, що різні вузли мають різне число зв'язків, і новий вузол з більшою ймовірністю приєднується до найбільш розгалуженого вузла (hub), тому що ймовірність зустрітися 3 ним на транспортному ринку набагато вища, ніж в одинаків. Динаміка розвитку мереж описується принципом, що більш успішні співтовариства розгалужуються і ще більше консолідують свої зусилля (див. рис. 5).

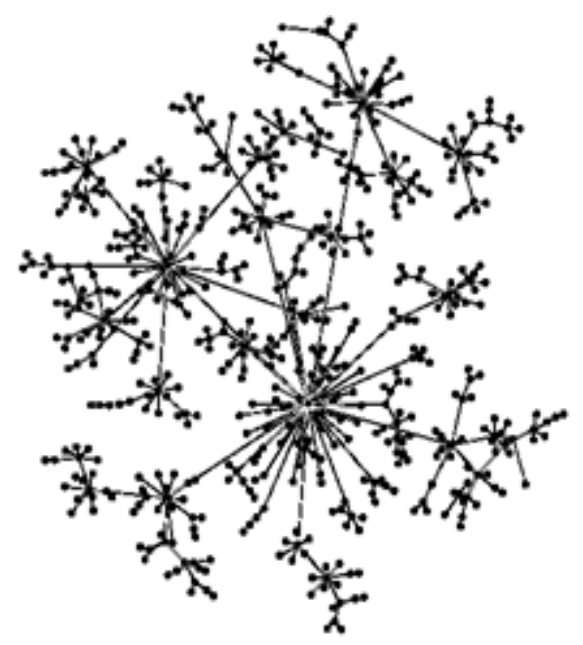

Рис. 5. Процес формування транспортних мереж
Виходячи із теорії КолмогороваАрнольда-Мозера (КАМ-теорії) нелінійний резонанс показує, що навіть невеликі збурювання можуть досить істотно вплинути на динаміку інтегрувальної гамільтонової системи [11]. Розглянемо незбурену повністю інтегрувальну систему 3 гамільтоніаном $H=H_{0}(J)$. У змінних динаміка описується рівняннями:

$$
\begin{aligned}
\alpha_{i} & =\frac{\partial H}{\partial J_{i}}, \\
\dot{J}_{i} & =0, \quad i=1,2, \ldots, n .
\end{aligned}
$$

Фазовий простір такої системи 2n-розмірний і являє собою сукупність $n$-розмірних інваріантних торів.

Умови застосовуваності КАМ-теорії такі:

1) незбурений гамільтоніан повинен задовольняти умови невироджуваності

$$
\operatorname{det}\left|\frac{\partial \omega_{i}}{\partial J_{k}}\right|=\operatorname{det}\left|\frac{\partial^{2} H_{0}}{\partial J_{i} \partial J_{k}}\right| \neq 0, \quad i=1,2, \ldots, n .
$$

Це означає, що частоти незбуреної системи функціонально незалежні;

2) збурювання повинне бути гладким, тобто гамільтоніан $H_{1}$ має достатню кількість похідних;

3) система повинна перебувати поза резонансом, тобто

$$
\left|\sum_{j} k_{j} \omega_{j}\right|>c|k|^{-r}, \quad k=\left(k_{1}, k_{2}, \ldots, k_{n}\right),
$$

де $r$ залежить від степенів свободи $n$, а постійна $c$ визначається величиною збурювання $\in H_{1}$ i параметром нелінійності $\gamma$.

Мережа, що самоорганізується, має характеристики, відмінні від характеристик звичних систем. У першу чергу мова йде про те, що статистичні характеристики мережі підпорядковуються не загальному закону нормального розподілу парку вантажних вагонів, а закону «роwer law» (рис. 6). 

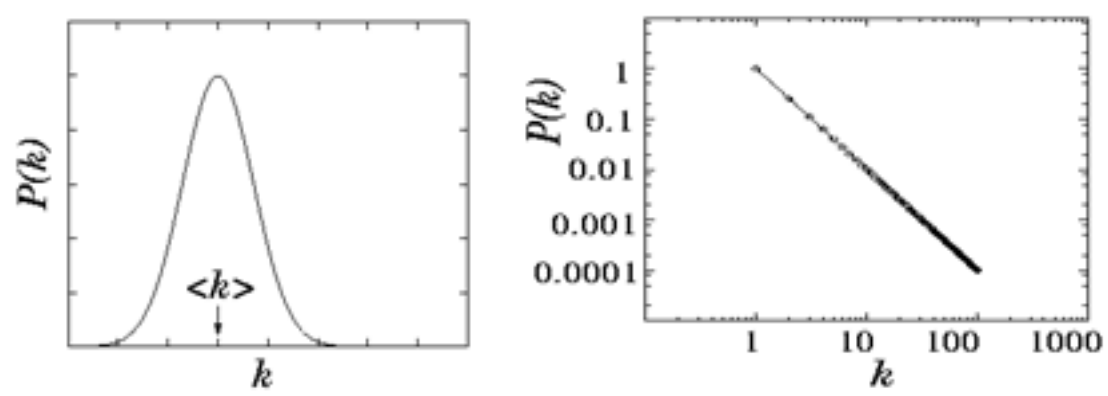

Рис. 6. Нормальний закон розподілу та «power law» парку вантажних вагонів різних власників

Якісна відмінність цих законів полягає в тому, що ймовірність більших відхилень виявляється значно вище. Інакше кажучи, на частку невеликої кількості вузлів припадає гнітюче число зв'язків. Крім того, боротьба за зв'язки не $\epsilon$ антагоністичною і вузли з більшою кількістю зв'язків (hubs) можуть мирно співіснувати 3 менш розгалуженими вузлами. Така система є надзвичайно життєздатною. До $80 \%$ вузлів дає змогу системі вижити за умови збереження невеликої кількості hubs. У той же час у таких систем є своєї недоліки: віруси, хвороби, економічний крах, що стрімко вражають всю транспортну мережу, якщо порушені іiі найбільш розгалужені вузли.

Таким чином, необхідне розуміння того, що наслідки зусиль, які уживаються операторами перевезень та структурними підрозділами залізниць, носять нелінійний характер. Перевага взаємозалежних систем полягає в тому, що виникає можливість одержання небачених винагород завдяки економіці зростаючої віддачі, і в той же час у ситуації, коли все 3 усім зв'язано прямим або непрямим чином, Зміни в одній частині системи, пройшовши через павутину зв'язків, можуть заподіяти несподівану i серйозну втрату системі, хоч економічний механізм працює бездоганно. Природа транспортних мереж - це складне сплетення ризиків і можливостей. Вони підсилюють ризик, але й підвищують гнучкість, збільшують можливості технічних інновацій, знижують рівень складності для окремих учасників.
Висновки 3 дослідження і перспективи, подальший розвиток у даному напрямку. Кількість парку вагонів, що належать ЗА або ОК, для забезпечення прогнозованих обсягів перевезень вантажів, крім перерахованих вище чинників, тобто: середньомісячного обсягу перевезень; нормативного обороту вантажного вагона в умовах ЄСУ ПВВ; середнього статичного навантаження вагонів; додаткових витрат часу на підготовку, технічне обслуговування, ремонт вагонів - має враховувати додаткові витрати часу через недотримання сторонами договірних зобов'язань, які приводять до збільшення нормативних (технологічних) строків доставки вантажів і обороту вагонів.

Співвідношення нормативних обсягів парку вантажних вагонів і оптимальних потреб користувачів послуг залізничного транспорту повинні сприяти забезпеченню взаємовигідної економії при взаємодії 3А, користувачів залізничних послуг, підприємств-власників вагонного парку та ОК шляхом створення моделі транспортного ринку операторів перевезень «Fitness Landscape».

Необхідно проводити моніторинг обсягів перевезень маршрутного і повагонного способів перевезень вантажів кожного фрахтового року й кількості парку вантажних вагонів для ЗА і для кожної ОК.

Збільшення рівня ефективності використання та обороту вантажних вагонів парку різних власників за рахунок скорочення непродуктивних простоїв дає додатковий ресурс для збільшення обсягів вантажоперевезень 3А, ОК. 


\section{Список використаних джерел}

1. ERRAC work package 02: Encouraging modal shift (long distance) and decongesting transport corridors. Freight Roadmap. July 2012 [Електронний ресурc]. - Режим доступу: www/URL: http://www.errac.org/wp-content/uploads/2013/07/14.-ERRAC-Freight-roadmap-2012-final.pdf. - Загол. 3 екрана.

2. Державна цільова програма реформування залізничного транспорту на 2010-2019 роки [Електронний ресурс]: затв. постановою Кабінету міністрів України №1390 від 16 грудня 2009 р. в редакції постанови КМУ №1106 від 26.10.2011 р., №1146 від 09.11.2011 р. - Режим доступу: www/URL: http://zakon2.rada.gov.ua/laws/show/1390-2009-\%D0\%BF/page. - Загол. з екрана.

3. Управление парками вагонов стран СНГ и Балтии на железных дорогах России [Текст]: учеб. пособие для вузов ж.-д. трансп. / В.И. Ковалев, С.Ю. Елисеев, А.Т. Осминин [и др.]; под ред. В.И. Ковалева, С.Ю. Елисеева, Е.Ю. Мокейчева. - М.: Маршрут, 2006. - 245 с.

4. Иловайский, Н.Д. Сервис на транспорте (железнодорожном) [Текст] / Н.Д. Иловайский. - М.: Транспорт, 2003. - 218 с.

5. Данько, М.I. Визначення парку вагонів операторських компаній для забезпечення перевезень вантажів залізничним транспортом [Текст] / М.І. Данько, В.В. Кулешов // Зб. наук. праць. - Харків: УкрДАЗТ, 2004. - Вип. 57. - С. 121-128.

6. Данько, Н.И. Разработка организационно-технологической модели управления парком грузовых вагонов разной формы собственности [Текст] / Н.И. Данько, Д.В. Ломотько, В.В. Кулешов // Инновационный транспорт. Научно-публицистическое издание. - 2012. - №4(5). - С. 8-13.

7. Кулешов, В.В. Удосконалення інформаційної технології роботи з вагонами різних форм власності з метою оптимізації пропускної спроможності залізничних транспортних систем [Текст] / В.В. Кулешов // Зб. наук. праць Укр. держ. акад. залізничн. трансп. - Харків: УкрДАЗТ, 2011. Вип. 124. - С. 83-90.

8. Бодюл, В.И. Система управления перевозками грузов для операторов железнодорожного подвижного состава [Текст] / В.И. Бодюл, А.Н. Феофилов // Наука и техника транспорта. - 2012. Вып. 1. - С. 57-62.

9. Kauffman S. (1993), Origins of Order: Self-Organisation and Selection in Evolution [Text] // Oxford: Oxford University Press.

10. Шикин, Е.В. Математические методы и модели в управлении [Текст] / Е.В. Шикин, А.Г. Чхартишвили. - М.: Дело, 2004. - 437 с.

11. Лоскутов, А.Ю. Основы теории сложных систем [Текст] / А.Ю. Лоскутов, А.С. Михайлов. М.; Ижевск: Институт компъютерных исследований, 2007. - 620 с.

Рецензент д-р техн. наук, професор Є.С. Альошинський

Кулешов Валерій Вячеславович, кандидат технічних наук, доцент, кафедра залізничних станций та вузлів. Даниленко Руслан Едуардович, Лупир Альона Сергіївна, магістри, случачі групи 13-VI-УППм. Український державний університет залізничного транспорту. Тел.: (057) 730-10-42. E-mail: kharkov-kuleshov@yandex.ua.

Kuleshov Valery Vyacheslavovich, Candidate of technical sciences, associate professor. The Department of railway stations and units.

Danilenko Ruslan Eduardovich, Lupyr Aliena Sergiivna. Masters Students group 13-VI-UPPm. Ukrainian State University of Railway Transport. Tel.: (057) 730-10-42. E-mail: kharkov-kuleshov@yandex.ua.

Стаття прийнята 7.07.2015 p. 